\title{
IMPLEMENTASI KEBIJAKAN PERMENDIKNAS NOMOR 24 TAHUN 2008 TENTANG TENAGA ADMINISTRASI SMA DAN SMK NEGERI KOTA PEKANBARU
}

\author{
Ahmad Husaini 1) \\ Azhar 2) \\ Sumarno ${ }^{3)}$ \\ 1) Guru SMK Negeri 4 Pekanbaru \\ 2) Lecture of Education Administration Study Programme PPs University of Riau \\ 3) Lecture of Education Administration Study Programme PPs University of Riau \\ Email: amandahusaini@gmail.com
}

\begin{abstract}
Implementation of Minister of National Education Policy No. 24 years 2008 concerning Administrative Personnel at Pekanbaru City High School and Vocational High School (Supervised by Dr. Azhar, S.Pd, M.T and Dr. Sumarno, M.Pd, M.Si) Riau University Postgraduate Thesis 2020.This research is a qualitative research, which aims to obtain information in the implementation of the Ministry of Education and Culture Policy No. 24 years 2008 on Administrative Personnel SMA and SMK Negeri Pekanbaru City. This research focuses on assessing the process of implementing the Minister of National Education Policy No. 24 years 2008. The research sub-focus consists of: 1). The communication process in the implementation of the Minister of Education's Regulation No. 24 years 2008 on Administration personnel SMA and SMK Negeri Pekanbaru City. 2). The Ability of Resources in the implementation of the National Education Minister Regulation No. 24 years 2008 concerning administrative staff SMA and SMK Negeri Pekanbaru City. 3). The disposition process in the implementation of Permendiknas Policy No. 24-2008 concerning Administration personnel SMA and SMK Negeri Pekanbaru City. 4). The ability of the bureaucratic structure in implementing Ministerial Regulation No. 24 years 2008 on Administration personnel SMA and SMK Negeri Pekanbaru City.The results achieved from this study are that the implementation of the Ministry of National Education Policy No. 24 years 2008 concerning Administration personnel SMA and SMK Negeri Pekanbaru City has not been implemented properly as a whole, especially in the ability of resources and bureaucratic structures, but it is not an obstacle in implementing policies, this is can be proven by the existence of administrative service activities at school that have been going well.
\end{abstract}

Keywords: Implementation; Policy; Ministerial Regulation; Administrative Staff 


\section{ABSTRAK}

Implementasi Kebijakan Permendiknas Nomor 24 Tahun 2008 Tentang Tenaga Administrasi SMA dan SMK Negeri Kota Pekanbaru (Dibimbing oleh Dr. Azhar,S.Pd,M.T dan Dr. Sumarno,M.Pd,M.Si) Tesis Program Pascasarjana Universitas Riau 2020.Penelitian ini adalah penelitian kualitatif, yang bertujuan untuk memperoleh informasi dalam pengimplementasian Kebijakan Permendiknas Nomor 24 tahun 2008 tentang tenaga administrasi SMA dan SMK Negeri Kota Pekanbaru. Penelitian ini memfokuskan pada pengkajian proses pengimplementasian Kebijakan Permendiknas Nomor 24 Tahun 2008 tersebut . Subfokus penelitian ini terdiri dari : 1). Proses komunikasi dalam implementasi kebijakan Permendiknas No 24 tahun 2008 tentang tenaga administrasi SMA dan SMK Negeri Kota Pekanbaru. 2).Kemampuan Sumberdaya dalam implementasi kebijakan Permendiknas No 24 Tahun 2008 tentang tenaga administrasi SMA dan SMK Negeri Kota Pekanbaru. 3). Proses disposisi dalam implementasi kebijakan Permendiknas No 24 tahun 2008 tentang tenaga administrasi SMA dan SMK Negeri Kota Pekanbaru. 4). Kemampuan struktur birokrasi dalam implementasi kebijakan Permendiknas No 24 tahun 2008 tentang tenaga administrasi SMA dan SMK Negeri Kota Pekanbaru.Hasil yang dicapai dari penelitian ini bahwa Implementasi Kebijakan Permendiknas No 24 Tahun 2008 tentang tenaga administrasi SMA dan SMK Negeri Kota Pekanbaru belum terimplementasi dengan baik secara keseluruhan, terutama pada kemampuan sumber daya dan struktur birokrasi, namun tidak menjadi halangan dalam pelaksanaan kebijakan, hal ini dapt dibuktikan dengan adanya kegiatan pelayanan keadministrasian disekolah sudah berjalan dengan baik.

Kata Kunci: Implementasi; Kebijakan; Permendiknas; Tenaga Administrasi

\section{PENDAHULUAN}

Sekolah sebagai lembaga pendidikan merupakan lembaga yang berperan penting dalam menghasilkan Sumber Daya Manusia (SDM) yang memiliki kualifikasi dan kompetensi tinggi. Sekolah dituntut untuk mampu memberikan kontribusi yang positif terhadap pembangunan dan peningkatan SDM. Sekolah merupakan salah satu lembaga pendidikan yang dibuat pemerintah dan pihak swasta sebagai tempat terbaik untuk belajar sehingga diharapkan dapat menciptakan manusia seutuhnya dengan mengembangkan kemampuan intelektual, potensi, spiritual, kepribadian dan sosial dalam membentuk watak manusia. Oleh karena itu sekolah harus dikelola secara efektif dan efisien untuk mencapai tujuan tersebut.

Sesuai aturan kepegawaian, tugas tenaga administrasi sekolah di jenjang pendidikan tidak boleh dirangkap oleh tenaga fungsional yang lain. Sebagai subsistem atau komponen pembelajaran, keberadaannya akan saling berkaitan dengan komponen yang lain agar tujuan pendidikan dapat dicapai sesuai dengan harapan. Keberadaan subsistem atau komponen tersebut harus memenuhi syarat baik dari segi kuantitas maupun kualitasnya sesuai dengan Standar Nasional Pendidikan sehingga hasil yang diharapkan dalam tujuan pembelajaran pada setiap satuan pendidikan dapat dicapai sesuai dengan rencana strategis yang telah ditetapkan. 
Masalah mutu dan kinerja pegawai tenaga administrasi sekolah pada kenyataannya masih luput dari pantauan banyak orang sehingga pegawai tenaga administrasi belum memberikan kontribusi yang signifikan terhadap peningkatan mutu pendidikan. Harus disadari bahwa kinerja tenaga administrasi merupakan salah satu faktor yang mempengaruhi mutu sebuah sekolah. Tetapi kenyataanya upaya peningkatan mutu dan kinerja pegawai tenaga administrasi sekolah masih kurang mendapat perhatian. Selama ini, peningkatan kualitas pendidikan hanya menyoroti pada permasalahan guru, peningkatan kinerja kepala sekolah serta kurikulum siswa yang senantiasa berubahubah. Jarang kita jumpai seorang pegawai tenaga administrasi mendapatkan pelatihan-pelatihan, diklat, maupun seminar.

Dalam Permendiknas Nomor 24 tahun 2008 tentang Standar Tenaga Administrasi Sekolah/Madrasah menjelaskan bahwa tenaga administrasi sekolah/madrasah terdiri atas kepala tenaga administrasi sekolah/madrasah, pelaksana urusan, dan petugas layanan khusus. Pelaksana urusan meliputi pelaksana urusan: administrasi kepegawaian, administrasi keuangan, administrasi sarana dan prasarana, administrasi humas, administrasi persuratan dan kearsipan, administrasi kesiswaan, administrasi kurikulum, dan administrasi umum untuk SD/MI/SLB (Sari, 2018). Petugas layanan khusus, meliputi penjaga sekolah, tukang kebun, pengemudi dan pesuruh. Berdasarkan peraturan tersebut, untuk dapat diangkat sebagai tenaga administrasi sekolah/madrasah, seseorang wajib memenuhi standar tenaga administrasi sekolah/madrasah yang berlaku secara nasional (Rokhmaniyah, 2017)

Menurut pendapat Lilis (2016) menyatakan bahwa kompetensi yang ha- rus dimiliki oleh Tenaga Administrasi Sekolah/Madrasah mencakup kompetensi kepribadian, sosial, teknis dan manajerial. Pelaksana urusan meliputi kompetensi kepribadian, sosial, teknis, sedangkan petugas Layanan Khusus mencakup kompetensi kepribadian, sosial dan teknis petugas layanan khusus.

Suranto (2014) menyatakan bahwa Tenaga Administrasi Sekolah merupakan tenaga kependidikan yang memegang peran penting dalam meningkatkan layanan administrasi sekolah. Terkait dengan hal tersebut maka tenaga administrasi sekolah perlu memiliki kompetensi dan kualifikasi pendidikan serta pengalaman kerja yang dipersyaratkan agar dapat melaksanakan tugas dan fungsinya dengan baik. (Mulyadi, 2018 dan Rumanti, 2014). Menurut Rumanti (2014) menyatakan tenaga kependidikan bertugas melaksanakan administrasi, pengelolaan, pengembangan, pengawasan, dan pelayanan teknis untuk menunjang proses pendidikan pada satuan pendidikan. Kemudian, menurut Sagala tenaga administrasi atau ketatausahaan bertugas membantu kepala sekolah, guru dan tenaga kependidikan dalam kelancaran kegiatan administrasi ketatausahaan, kepegawaian, keuangan perlengkapan dan logistik sekretariat dan surat menyurat, kepeserta didikan, transportasi, dan sebagainya yang berhubungan dengan teknis administratif (Jaka, 2013)

Dari pendapat lain Rumanti (2014) menyatakan dukungan administrasi bukan saja dalam rangka memperlancar pelaksanaan kegiatan pokok yang bersifat rutin tetapi juga dalam rangka pengembangan sekolah. Keefektifan sebuah sekolah banyak ditentukan oleh kualitas dan kompetensi tenaga 
kependidikan sekolah yang bersangkutan (Mulyadi, 2013).

Selanjutnya dalam Permendiknas Nomor 24 tahun 2008 mengenai Standar Tenaga Administrasi sekolah harus memiliki kemampuan atau kompetensi yaitu kompetensi kepribadian, kompetensi sosial, kompetensi teknis, dan kompetensi manajerial (khusus Kepala Tenaga Administrasi Sekolah). Pelayanan prima disini adalah salah satu bagian dari komptensi sosial yang harus dimiliki oleh tenaga administrasi sekolah disamping kompetensi-kompetensi lainnya. Kegiatan pelayanan ini identik dengan sikap dan perilaku dari tenaga administrasi sekolah dalam melaksanakan tugasnya. Tenaga administrasi sekolah memiliki tugas melayani secara prima membantu pelanggan dalam memenuhi kebutuhannya dan dilakukan dengan cara yang terbaik sehingga pelanggan merasa sangat puas (Kemendiknas, 2010).

Dari yang diharapkan oleh Permendiknas No 24 tahun 2008 tersebut masih ditemukan bahwa pelayanan disekolah saat ini cenderung masih lamban, tidak tepat waktu, kurang ramah, kurang komunikatif, dan bahkan masih ada juga memakai bahasa yang tidak enak didengar. Masih banyak ditemukan dalam sebuah lembaga pendidikan terutama pada SMA dan SMK Negeri di Kota Pekanbaru.

Berdasarkan hasil pengamatan pendahuluan dijumpai keadaan dengan fakta fakta sebagai berikut:

1) Masih banyak tenaga administrasi yang belum atau bahkan memiliki kemampuan atau kompetensi yang di syaratkan oleh Permendiknas No 24 tahun 2008, kecakapan atau keahlian yang memadai untuk mengerjakan tugas-tugas mereka dengan performa yang baik dan memuaskan. Hal ini dapat dilihat dari:

- Masih ada tenaga administrasi yang belum mahir mengoperasikan komputer dengan baik untuk urusan administrasi tenaga administrasi sekolah, padahal hampir semua urusan administrasi sekolah sekarang menggunakan komputer.

- Pekerjaan tenaga administrasi sekolah yang masih semrawut, seperti pengarsipan surat yang tidak rapi, data-data sekolah yang tidak lengkap maupun tidak up to date.

2) Masih rendahnya disiplin, loyalitas dan tanggung jawab pegawai Tenaga Administrasi dalam merencanakan dan melaksanakan tugas-tugas mereka sebagai pegawai tenaga administrasi sekolah.

3) Masih belum tercerminnya pelayanan prima yang diberikan tenaga administrasi kepada siswa, orang tua dan masyarakat.

4) Masih belum nampaknya kecerdasan emosional, spiritual, dan bahkan juga kecerdasan intelektual tenaga administrasi dalam memecahkan berbagai permasalahan serta dalam berinteraksi di lingkungan.

5) Masih terdapat pekerjaan yang menumpuk pada satu orang pegawai karena dianggap mampu sehingga sistem keadmiitrasian terkesan berjalan lambat.

6) Masih terdapat sekolah yang melibatkan guru sebagai tenaga administrasi sehingga akan mengganggu tugas pokoknya sebagai guru.

Untuk memahami fakta yang lengkap dan mendalam maka peneliti mengambil judul Penelitian "Implementasi Kebijakan 
Permendiknas Nomor 24 Tahun 2008 Tentang Tenaga Administrasi SMA dan SMK Negeri Kota Pekanbaru’”.

\section{METODOLOGI PENELITIAN}

Penelitian ini dilaksanakan dengan metode kualitatif dengan pendekatan naturalistik dalam observasi dan pengumpulan datanya, dan peneliti sendiri dalam penelitian ini berfungsi sebagai instrumen utama. Ada beberapa definisi mengenai penelitian kualitatif, Bogdan dan Taylor (Moleong, 1988) mendefinisikan "metodologi kualitatif" sebagai prosedur penelitian yang menghasilkan data deskriptif berupa: kata-kata tertulis atau lisan dari orangorang dan perilaku yang dapat diamati. Sejalan dengan pengertian tersebut, Kirk dan Miller (Moleong, 1988) mendefinisikan bahwa penelitian kualitatif adalah tradisi tertentu dalam ilmu pengetahuan sosial yang secara fundamental bergantung pada pengamatan pada manusia dan kawasannya sendiri dan berhubungan dengan orang-orang tersebut dalam bahasanya dan dalam peristilahannya. Sedangkan oleh Satori dan Aan (2009), dikatakan bahwa penelitian kualitatif adalah penelitian yang menekankan pada quality atau hal yang terpenting dari sifat suatu barang/jasa. Hal terpenting dari suatu barang atau jasa berupa kejadian/fenomena/gejala sosial adalah makna dibalik kejadian tersebut yang dapat dijadikan sebagai pelajaran berharga bagi suatu pengembangan konsep teori

Selanjutnya jenis penelitian ini adalah penelitian studi kasus yang terjadi dilapangan. Mudjia Rahardjo (2012), menjelaskan bahwa penelitian studi kasus adalah penelitian yang mendalam tentang individu, satu kelompok, satu organisasi, satu program kegiatan, dan sebagainya dalam waktu tertentu. Tujuannya untuk memperoleh diskripsi yang utuh dan mendalam dari sebuah entitas. Studi kasus menghasilkan data untuk selanjutnya dianalisis untuk menghasilkan teori. Sebagaimana prosedur perolehan data penelitian kualitatif, data studi kasus diperoleh dari wawancara, observasi, dan arsip. Iyan Afriani H. S (2013), juga menjelaskan bahwa penelitian studi kasus adalah studi yang mengeksplorasi suatu masalah dengan batasan terperinci, memiliki pengambilan data yang mendalam, dan menyertakan berbagai sumber informasi. Penelitian ini dibatasi oleh waktu dan tempat, dan kasus yang dipelajari berupa program, peristiwa, aktivitas, atau individu. Penelitian case study atau penelitian lapangan (field study) dimaksudkan untuk mempelajari secara intensif tentang latar belakang masalah keadaan dan posisi suatu peristiwa yang sedang berlangsung saat ini, serta interaksi lingkungan unit sosial tertentu yang bersifat apa adanya (given). Penelitian studi kasus akan kurang kedalamannya bilamana hanya dipusatkan pada fase tertentu saja atau salah satu aspek tertentu sebelum memperoleh gambaran umum tentang kasus tersebut. Sebaliknya studi kasus akan kehilangan artinya kalau hanya ditujukan sekedar untuk memperoleh gambaran umum namun tanpa menemukan sesuatu atau beberapa aspek khusus yang perlu dipelajari secara intensif dan mendalam.

Proses penelitian kualitatif, disajikan menurut tahap-tahapnya (Rahardjo, 2010), yaitu: (1) Tahap Pralapangan, (2) Tahap Kegiatan Lapangan, dan (3) Tahap Pasca-lapangan. 


\section{HASIL PENELITIAN DAN PEMBA- HASAN}

Pada bagian ini seluruh data yang telah didapat selama proses penelitian dianalisis sesuai dengan fokus kajian penelitian. Data tersebut diperoleh menggunakan metode wawancara berdasarkan interview guide, observasi dan dokumentasi terhadap fenomenafenomena yang berkaitan dengan judul penelitian. Pembahasan mengenai implementasi kebijakan Permendiknas No 24 tahun 2008 tentang tenaga adminitrasi SMA Negeri dan SMK Negeri Kota Pekanbaru.

Pada kebijakan Permendiknas No 24 tahun 2008 tentang tenaga adminitrasii SMA Negeri dan SMK Negeri Kota Pekanbaru ,diharapkan dengan dipilihnya dua SMA Negeri dan dua SMK Negeri di Kota Pekanbaru dapat memberikan gambaran tentang Implementasi Permendiknas No 24 tahun 2008 tersebut di Kota Pekanbaru. Menurut model implementasi kebijakan yang diungkapkan oleh George C. Edward III yaitu Implementasi kebijakan dipengaruhi oleh beberapa faktor, diantaranya komunikasi, sumberdaya, disposisi dan struktur birokrasi yang saling berhubungan. Melalui pembahasan ini peneliti dapat mengetahui implementasi kebijakan Permendiknas No 24 tahun 2008 tentang tenaga adminitrasi SMA Negeri dan SMK Negeri Kota Pekanbaru.

Pembahasan ini menjawab tujuan penelitian implementasi Kebijakan Permendiknas No 24 tahun 2008 tentang tenaga adminitrasi SMA Negeri dan SMK Negeri Kota Pekanbaru dengan melihat model implementasi yang diungkapkan oleh George C. Edwards III yang mempengaruhi keberhasilan dari implementasi kebijakan yang diteliti penulis.

\subsubsection{Subfokus Proses Komunikasi Da- lam Implementasi Kebijakan Permendiknas No 24 Tahun 2008 Tentang Tenaga Admin- istrasi SMA dan SMK Negeri Kota Pekanbaru.}

Menurut Edward dalam Budi Winarno (2007), komunikasi berkenaan dengan bagaimana kebijakan dikomunikasikan kepada organisasi dan/atau publik dan sikap serta tanggapan dari pra pihak yang terlibat. Sedangkan pengertian komunikasi itu sendiri merupakan proses penyampaian informasi dari komunikasi kepada komunikan. Komunikasi sangat menentukan keberhasilan pencapaian tujuan dari implementasi kebijakan publik. Selain itu, kebijakan yang dikomunikasikan pun harus tepat, akurat dan konsisten.

Komunikasi merupakan salah satu elemen penting yang mempengaruhi implementasi kebijakan publik. Keberhasilan sebuah kebijakan dapat dilihat dari komunikasi yang ada. Kebijakan harus disampaikan kepada pihak-pihak yang terkait, sehingga informasi yang disampaikan harus akurat. Apabila penyampaian tujuan dan sasaran suatu kebijakan tidak jelas, tidak memberikan pemahaman atau bahkan tujuan dan sasaran kebijakan tidak diketahui sama sekali oleh kelompok sasaran, maka kemungkinan akan terjadi suatu penolakan atau resistensi dari kelompok sasaran yang bersangkutan.

Oleh karena itu diperlukannya tiga hal, yaitu penyaluran (transmisi) yang baik akan mengahsilkan implementasi yang baik pula, adanya kejelasan yang diterima oleh pelaksana kebijakan sehingga tidak membingungkan dalam pelaksanaannya, dan adanya konsistensi 
yang diberikan pelaksanaan kebijakan. Jika yang dikomunikasikan berubah ubah akan membingungkan dalam pelaksanaan kebijakan yang bersangkutan. Peneliti membahas fenomena komunikasi dengan memperhatikan transmisi dan kejelasan yang disesuaikan dengan hasil penelitian.

Faktor pertama yang berpengaruh terhadap komunikasi kebijakan adalah transmisi. Transmisi komunikasi atau penyaluran komunikasi yang baik akan dapat menghasilkan suatu implementasi yang baik pula. Koordinasi pelaksanaan kebijakan Permendiknas No 24 tahun 2008 dari Pemerintah daerah dalam hal ini dari Dinas Pendidikan Provinsi tidak terimplimentasi dengan baik ke pihak sekolah. Seluruh kepala sekolah belum pernah mendapatkan sosialisasi berkenaan dengan faktor komunikasi secara resmi, melainkan kepala sekolah memperoleh materi kebijakan Permendiknas No 24 tahun 2008 pada saat ada Diklat Calon kepala Sekolah yang diselenggarakan oleh Pemerintah Pusat melalui Pemerintah Daerah. Sementara penyelenggaraan sosialisasi disekolah kepada seluruh tenaga administrasi berjalan dengan baik melalui rapat, workshop ataupun in house training secara rutin.

Faktor kedua adalah kejelasan. Indikator kejelasan komunikasi juga merupakan elemen yang penting. Kejelasan komunikasi menentukan akan keberhasilan implementasi sebuah kebijakan publik. Jika kebijakankebijakan diimplementasikan sebagaimana yang diinginkan, maka petunjuk-petunjuk pelaksanaan tidak hanya harus diterima oleh para pelaksana kebijakan, tetapi juga komunikasi kebijakan tersebut harus jelas. Ketidakjelasan pesan komunikasi yang disampaikan berkenaan dengan implementasi kebijakan akan mendorong terjadinya kesalahpahaman bahkan mungkin bertentangan dengan makna pesan awal. Kejelasan komunikasi dalam implementasi kebijakan Permendiknas No 24 tahun 2008 tentang tenaga administrasi SMA dan SMK Negeri Kota Pekanbaru dari penyampaian informasi oleh Dinas Pendidikan provinsi Riau ke pihak sekolah. Keterbukaan mengenai Permendiknas No 24 tahun 2008 dilakukan dengan tujuan agar seluruh tenaga pendidik maupun tenaga administrasi mengetahui secara jelas informasi apa saja yang telah disampaikan.

Berdasarkan hasil wawancara yang dilakukan, penulis menganalisis bahwa transmisi komunikasi atau penyaluran komunikasi, dan kejelasan komunikasi oleh Pemerintah Daerah dalam hal ini Dinas Pendidikan Provinsi belum berjalan dengan baik. Namun transmisi komunikasi dari Kepala Sekolah kepada tenaga administrasi sudah berjalan dengan baik. Penyampaian informasi yang dilakukan oleh Kepala Sekolah langsung dapat dengan mudah ditangkap atau dicerna oleh tenaga administrasi. Komunikasi yang terjadi dalam implementasi kebijakan Permendiknas No 24 tahun 2008 tentang tenaga administrasi SMA dan SMK Negeri Kota Pekanbaru dengan melihat segi transmisi dan kejelasan masih memiliki masalah yang menjadikan komunikasi sebagai faktor pendorong dalam implementasi kebijakan Permendiknas No 24 tahun 2008 SMA dan SMK Negeri Kota Pekanbaru.

Menurut George C. Edward III (dalam Agustino, 2008) adalah komunikasi. Komunikasi, menurutnya sangat menentukan keberhasilan pencapaian tujuan dari implementasi kebijakan publik. Implementasi yang efektif terjadi apabila para 
pembuat keputusan sudah mengetahui apa yang akan mereka kerjakan. Pengetahuan atas apa yang akan mereka kerjakan dapat berjalan apabila komunikasi berjalan dengan baik, sehingga setiap keputusan kebijakan dan peraturan implementasi harus ditransmisikan (atau dikomunikasikan) kepada bagian personalia yang tepat. Selain itu, kebijakan yang dikomunikasikan pun harus tepat, akurat, dan konsisten.

\subsubsection{Subfokus Kemampuan Sumber Daya Dalam Implementasi Ke- bijakan Permendiknas No 24 Ta- hun 2008 Tentang Tenaga Ad- ministrasi SMA dan SMK Negeri Kota Pekanbaru.}

Sumber daya menjadi salah satu faktor penting dalam implementasi kebijakan publik. Sumber daya meliputi sumber daya manusia, sumber daya anggaran, dan sumber daya fasilitas. Sumber daya menusia berkenaan dengan kecakapan pelaksana kebijakan publik untuk mengimplementasikan kebijakan secara efektif.

George Edward (dalam Tangkilisan, 2003), sumber daya dikatakan baik dilihat dari sumber daya manusia, anggaran dan fasilitas. Sumber daya manusia di dalam suatu organisasi merupakan hal yang penting. Ketersediaan staf beserta kualitas dalam penelitian ini adalah tentang ketersediaan satuan tugas yang dapat digunakan untuk menggantikan tugas tertentu dari implementor terhadap implementasi kebijakan Permendiknas No 24 tahun 2008 tentang tenaga administrasi SMA dan SMK Negeri Kota Pekanbaru. Penulis menganalisis secara kuantitas, ketersediaan jumlah sumber daya manusia yang dimiliki oleh sekolah belum memadai dan kurang jumlahnya, masih ada kualifikasi pendidikan, serta kompetensi yang belum memenuhi persyaratan kebijakan Permendiknas No 24 tahun 2008 tersebut. Ketersediaan jumlah yang kurang tersebut dikarenakan tidak ada penambahan tenaga administrasi dari pemerintah Daerah khususnya tenaga administrasi tyang berstatus Pegawai Negeri Sipil (PNS), masih banyak tenaga administrasi disekolah yang berstatus tenaga honorer. Secara kuantitas jumlah tenaga administrasi kurang memadai namun mereka bekerja secara maksimal walaupun masih ada tenaga administrasi yang memiliki tugas rangkap, sehingga secara kualitas pun juga masih dapat dikatakan berkurang. Karena dalam Permendikans No 24 tahun 2008, seyogyanya satu bidang pekerjaan dikerjakan oleh satu orang tenaga administrasi. Lalu dalam pengawasan yang dilakukan oleh pimpinan yakni Kepala Sekolah dengan dibantu oleh Kepala Tenaga Administrasi sudah berjalan dengan baik. Dalam hal pengawasan ini dibantu oleh laporan laporan dan pekerjaan yang mereka kerjakan. Apabila implementor kekurangan sumberdaya manusia untuk melaksanakan, implementasi kebijakan tidak akan berjalan efektif dan efisien. Suatu kebijakan tidak akan berjalan dengan baik apabila tanpa dukungan sumber daya anggaran. Maka dari itu sumber daya anggaran menjadi salah satu faktor yang cukup penting demi berjalannya kebijakan ini dengan baik. Anggaran berkaitan dengan kecukupan modal atas suatu kebijakan untuk menjamin terlaksananya kebijakan, sebab tanpa adanya dukungan anggaran yang memadai, kebijakan tidak akan berjalan dengan efektif dalam mencapai tujuan dan sasaran. Implementasi kebijakan 
Permendikans No 24 tahun 2008 ini juga tidak dapat berjalan dengan baik apabila tanpa adanya dukungan dari anggaran. Anggaran yang disediakan oleh Pemerintah Pusat dan Daerah melalui dana Bosnas dan Bosda sudah mencukupi sesuai dengan Rencana Anggaran yang dibuat oleh sekolah.,

Sumber daya fasilitas termasuk faktor yang tidak kalah pentingnya dengan sumber daya lainnya dalam implementasi kebijakan Permendikans No 24 tahun 2008 ini. Pengadaan fasilitas penunjang yang layak seperti gedung, dan peralatan penunjang akan menunjang implementasi suatu kebijakan. Dengan adanya fasilitas yang baik maka akan menunjang keberhasilan kebijakan Permendikans No 24 tahun 2008 . Berdasarkan hasil wawancara dapat diketahui bahwa fasilitas untuk melaksanakan kebijakan penyelenggaraan reklame sudah cukup memadai baik secara kuantitas maupun kualitas bagi sekolah yang berada ditengah kota dan yang memiliki jumlah siswa yang banyak, sedangkan sekolah yang dipinggir kota dan memiliki jumlah siswa yang sedikit masih belum memadai dan masih sangat terbatas. Fasilitas yang dimaksud cukup memadai untuk menunjang keberhasilan kebijakan ini yakni fasilitas yang disediakan oleh pemerintah yakni ruangan yang nyaman, perangkat computer yang cukup, akses internet dan sarana penunjang lainnya. Ketersediaan sumber daya merupakan salah satu syarat keberhasilan dalam implementasi sebuah kebijakan.

Berdasarkan pada pendapat George C. Edwards III, meskipun komunikasi sudah dilaksanakan dengan jelas dan konsisten, tetapi jika pelaksana kebijakan kekurangan sumberdaya yang diperlukan untuk melaksanakan kegiatan-kegiatan dalam implementasi, maka kebijakan implementasi kebijakan sulit dilakukan. Ketersediaan Sumber Daya Manusia dalam hal pengimplementasian Permendiknas No 24 tahun 2008 tentang tenaga administrasi SMA dan SMK Negeri Kota Pekanbaru di level sekolah masih kurang sehingga kinerja tenaga administrasi untuk menyelasaikan pekerjaan masih kurang efektif, tetapi karena membebani pekerjaan diluar kemampuan dan berdampak pada pelaksanaan kebijakan menjadi tidak efektif.

\subsubsection{Subfokus Proses Disposisi Dalam Implementasi Kebijakan Permendiknas No 24 Tahun 2008 Tentang Tenaga Admin- istrasi SMA dan SMK Negeri Kota Pekanbaru}

Disposisi adalah watak atau karakteristik yang dimiliki oleh implementor. Disposisi menentukan keberhasilan sebuah implementasi kebijakan. Apabila implementor memiliki disposisi yang baik maka dia akan dapat menjalankan kebijakan dengan baik seperti apa yang diinginkan oleh pembuat kebijakan.

Disposisi memegang salah satu peran penting dalam keberhasilan sebuah implementasi kebijakan. Hal ini dikarenakan dalam menjalankan tugasnya, seseorang harus paham dan memiliki pandangan yang baik terkait dengan kebijakan tersebut (Budi Winarno, 2007). Disposisi pada penelitian ini adalah tentang komitmen. Komitmen dibuktikan dengan melihat alasan implementor untuk dapat melaksanakan implementasi, tujuan/perubahan yang ingin dicapai, dan perubahan yang telah dicapai para implementor untuk 
implementasi kebijakan Permendikans No 24 tahun 2008.

Berdasarkan hasil wawancara dalam implementasi kebijakan Permendiknas No 24 tahun 2008 tentang tenaga administrasi SMA dan SMK Negeri Kota Pekanbaru, kemauan dan kesungguhan para pelaksana dalam melakukan implementasi kebijakan tersebut dinilai sudah baik. Walaupun dengan berbagai kekurangan dan kendala yang ada, mereka tetap berusaha untuk mensiasatinya untuk menunjang kelancaran pelaksanaan kebijakan.

Sesuai dengan teori Edward III, yang menjadi perhatian mengenai disposisi dalam implementasi kebijakan yaitu mengenai masalah rekruitmen tenaga administrasi dan pemberian insentif. Rekruitmen tenaga administrasi di sekolah sebagian besar merupakan tenaga honorer, dan sangat sedikit sekali yang berstatus Pegawai Negeri Sipil (PNS).

\subsubsection{Subfokus Kemampuan Struktur Birokrasi Dalam Implementasi Kebijakan Permendiknas No 24 Tahun 2008 Tentang Tenaga Administrasi SMA dan SMK Negeri Kota Pekanbaru}

Ada dua karakteristik utama dari birokrasi menurut Edward, yaitu prosedur - prosedur kerja ukuran ukuran dasar atau sering disebut sebagai Standard Operating Procedures (SOP) dan fragmentasi (Winarno, 2014). SOP yang baik adalah yang mencantumkan kerangka kerja yang jelas, sistematis, tidak berbelit-belit dan mudah dipahami oleh siapapun karena akan menjadi acuan dalam bekerja implementor.

Harapan dengan adanya SOP, sumber daya pengampu kebijakan mampu dapat menjalankan tugasnya sesuai dengan standar yang telah ditetapkan dalam SOP sehingga dapat menimbulkan efektivitas dan efisiensi kinerja, sedangkan struktur organisasi pelaksana pun sejauh mungkin menghindari hal yang berbelit, panjang dan kompleks.

Seluruh sekolah yang menjadi objek peneliti belum mempunyai SOP secara tertulis namun struktur birokrasi berjalan dengan baik sesuai dengan pembagian tugas dalam melakukan pelayanan.

Berdasarkan hasil wawancara penulis mendapatkan bahwa seluruh sekolah belum memiliki SOP dalam implementasi Permendiknas No 24 tahun 2008 ini, namun dalam pelaksanaan tugas ketenaga administrasian sudah berjalan dengan baik dan mereka bekerja berdasarkan tugas yang diberikannya.

Struktur birokrasi yang terdapat pada implementasi kebijakan Permendiknas No 24 tahun 2008 tentang tenaga administrasi SMA dan SMK Negeri Kota Pekanbaru tidak dapat dilihat dari aspek SOP dan aspek struktur birokrasinya, dikarenakan seluruh sekolah tidak memiliki SOP.

Pendapat Edward III dalam Widodo (2010), struktur birokrasi mencakup dimensi fragmentasi yaitu penyebaran tanggung jawab suatu kebijakan kepada beberapa badan yang berbeda sehingga memerlukan koordinasi. Selain itu, struktur birokrasi mencakup dimensi standar prosedur operasional yang akan memudahkan dan menyeragamkan tindakan dari pelaksana kebijakan dalam melaksanakan apa yang menjadi tugasnya.

Berdasarkan hasil pengamatan dan wawancara, struktur organisasi di sekolah menggambarkan jelas pemisahan kegiatan pekerjaan antara yang satu dengan yang lain sehingga hubungan aktivitas dan 
fungsi dibatasi. Implementasi Kebijakan Permendiknas No 24 tahun 2008 dimasing-masing sekolah belum memiliki SOP atau prosedur-prosedur kerja. Dalam melaksanakan prosedur kerja, tenaga administrasi di sekolah tetap menjalankan tugasnya sesuai dengan tugas dan tanggung jawab yang diberikan. Belum adanya SOP tersebut tentunya mengakibatkan tidak ada keseragaman para pelaksana dalam berkerja dikarenakan prosedur kerja yang digunakan masing-masing organisasi berbeda.

\section{SIMPULAN}

Setelah dilakukan analisis data berdasarkan telaah dokumen, pengamatan dan wawancara tentang implementasi kebijakan Permendiknas Nomor 24 tahun 2008 tentang tenaga administrasi SMA dan SMK Negeri Kota Pekanbaru, dapat ditarik kesimpulan sebagai berikut:

1. Dalam proses komunikasi berkaitan dengan sosialisasi tentang implementasi kebijakan Permendiknas Nomor 24 tahun 2008 belum berjalan dengan baik, ini dibuktikan dengan kurangnya sosialisasi dari dinas pendidikan provinsi secara khusus, tetapi hanya diberikan sekilas melalui rapat dinas ataupun pertemuan-pertemuan, sekolah melalui kepala sekolahnya menerima materi tersebut pada saat kepala sekolah mengikuti diklat pemenuhan calon kepala sekolah. Namun komunikasi dan sosialisasi ditingkat sekolah sudah cukup baik, sosialisasi tersebut disampaikan melalui rapat dan sekolah memberikan fasilitas internet untuk dapat mengakses informasi yang berkaitan dengan keadministrasian.
2. Dalam kemampuan sumber daya seluruh sekolah belum memiliki sumber daya yang dipersyaratkan oleh Permendiknas nomor 24 tahun 2008,namun sekolah memanfaatkan sumber daya yang sudah ada sesuai dengan kebutuhan sekolah masingmasing, dalam segi latar belakang pendidikan masih ada sekolah yang belum merujuk pada kebijakan Permendiknas No.24 tahun 2008 tersebut, karena masih ada sekolah yang memiliki tenaga administrasi yang berpendidikan SD dan SMP. Kebutuhan tenaga administrasi yang berstatus ASN masih sangat kurang, karena tenaga administrasi masih didominasi oleh tenaga honorer.

3. Dalam proses diposisi seluruh tenaga administrasi telah berkomitmen untuk mengimplementasikan kebijakan Permendiknas Nomor 24 tahun 2008, ini dapat dilihat dari tenaga administrasi yang sudah menunjukkan sikap positif dan mendukung kebijakan tersebut. Dengan kata lain seluruh tenaga administrasi disekolah sudah cukup baik, mereka selalu bekerja sesuai dengan tugas dan tanggung jawab yang diberikan berdasarakan job description nya masing-masing.

4. Dalam kemampuan struktur birokrasi secara garis besar seluruh sekolah belum mempunyai Standar Opersional Prosedur (SOP) secara tertulis pada setiap bagian atau setiap jenis pekerjaan, namun tenaga administrasi sudah menjalankan tugas sesuai dengan tugas yang diberikannya. Untuk struktur organisasi seluruh sekolah sudah membuat dengan baik dan diletakkan 
pada tempat yang mudah dilihat oleh orang lain.

Dalam pengimplementasian kebijakan Permendiknas No.24 tahun 2008 sekolah yang memiliki siswa sedikit dan yang memiliki siswa banyak dan yang memiliki siswa sedikit tidak terjadi perbedaan yang signifikan, pengimplementasiannya menyesuaikan dengan kebutuhan sekolahnya.

\section{UCAPAN TERIMA KASIH}

Pada akhirnya, penulis menyadari bahwaartikel ini tidak akan selesai tanpa dukungan dari rekan-rekan majelis guru SMK Negeri 4 Pekanbaru atas segala bantuan dan dukungan yang telah diberikan.

\section{DAFTAR PUSTAKA}

Bungin, B. (2011). Penelitian Kualitatif: Komunikasi, Ekonomi, Kebijakan Publik, Dan Ilmu Sosial Lainnya. In Kencana.

https://doi.org/10.1002/jcc.21776

Evaluasi Implementasi Kurikulum 2013 di Sekolah Pelaksana Mandiri. (2017). Innovative Journal of Curriculum and Educational Technology. https://doi.org/10.15294/ijcet.v6i1.1 5998

Lilis Suryani Octavia, \& Siti Ina Savira. (2016). Gaya Kepimpinan Kepala Sekolah Dalam Upaya Meningkatkan Kinerja Guru dan Tenaga Kependidikan. Jurnal Dinamika Manajemen Pendidikan. https://doi.org/10.2674/jdmp.v1n1.p $7-14$

Mulyadi, Hoiriah, Deddy Supriadi, R. M. (2018). Sistem Informasi Pendaftaran Kursus Berbasis Web Pada Yayasan Musik Jakarta. Ijcit.

Mulyadi, M. (2013). Penelitian Kuantitatif Dan Kualitatif Serta Pemikiran Dasar Menggabungkannya. Jurnal Studi Komunikasi Dan Media. https://doi.org/10.31445/jskm.2011. 150106

Patton \& Sawicki . (1987). Basic Methods of Policy Analysis \& Planning. New Jersey: Prentice-Hall.

Permendiknas Nomor 24 tahun 2008. (2008). [Permendiknas Nomor 24 tahun 2008 Tahun 2016 Nomor 24 Lampiran 17]. Animal Genetics.

Pressman \& Wildavsky . (1984). Aaron Implementation. California: University of California Press and Los Angles.

Rokhman, M. M., Wibowo, S. A., Pranoto, Y. A., \& Widodo, K. A. (2018). Pelatihan Pemanfaatan Microsoft Office Pada Staf Pengajar di SMPLBN (Sekolah Menengah Pertama Luar Biasa Negeri) Kota Malang. Jurnal MNEMONIC.

Suwitri, S. (2014). Konsep Dasar Kebijakan Publik Modul 1. Analisis Kebijakan Publik. https://doi.org/http://dx.doi.org/10.1 016/j.atmosenv.2007.12.054 
Winarno, B. (2002). Teori dan Proses

Kebijakan Publik. Yogyakarta:

Media Presindo. 